\title{
PENGENALAN EDUCATIONS FISHERIES PADA SISWA SEKOLAH DASAR MELALUI MODEL PEMBELAJARAN PROJECT BASED LEARNING
}

\author{
Sunarni ${ }^{1}$, Nova S. Monika ${ }^{2}$ \\ 1,2Jurusan Manajemen Sumberdaya Perairan, Universitas Musamus Merauke \\ Gd. Dekanat It. 2, JIn. Kamizaun Mopah Lama, Merauke, 99600 \\ Korespondensi:sunarni@unmus.ac.id
}

\begin{abstract}
ABSTRAK
Pembelajaran project based learning Merupakan proses pembelajaran yang secara langsung melibatkan siswa untuk menghasilkan sesuatu. Abidin (2007) menjelaskan model pembelajaran ini memiliki karakteristik diantaranya; melibatkan siswa secara langsung dalam pembelajaran, menghubungkan pembelajaran dengan dunia nyata dan Diakhiri dengan menghasilkan sebuah produk olahan ikan. Banyak masyarakat Merauke terutama anak-anak usia sekolah Lebih memilih produk makanan yang berasal dari daging ayam, daging sapi ataupun daging rusa dari pada ikan. Maka sangat perlu dilakukan pemberdayaan kepada anakanak agar gemar makan ikan melalui kegiatan pengenalan educations Fisheries pada siswa sekolah dasar. Metode pelaksanaannya meliputi; kegiatan pengenalan tentang jenis-jenis ikan (Education Fisheries), manfaat makan ikan dan kegiatan cooking class. Hasil kegiatan pengabdian siswa dapat membedakan jenis-jenis ikan yang hidup di daerah estuari dengan jenisjenis ikan yang hidup di air tawar maupun yang hidup di air laut, siswa dapat mengetahui manfaat makan ikan, serta siswa dapat mengetahui beberapa produk olahan dari ikan menjadi makanan yang menarik dan lebih digemari olah anak-anak.
\end{abstract}

Kata Kunci; Siswa, Ikan, Project Based Learning.

\section{PENDAHULUAN}

Merauke memiliki Sumberdaya alam hayati yang berlimpah hal ini didukung oleh banyaknya sungai-sungai yang bermuara ke Laut Arafura seperti Sungai Digul, Sungai Biam, Sungai Maro dan lain-lain. Salah satu sumberdaya alam hayati yang berlimpah di kota Merauke adalah ikan, baik ikan air tawar, air payau maupun ikan yang berasal laut. Kenyataan dilapangan banyak anak - anak belum bisa membedakan jenis-jenis ikan yang ada di kota Merauke bahkan banyak pula anak-anak belum mengetahui manfaat dari mengkonsumsi ikan. Anak -anak lebih suka mengkonsumsi daging ayam, daging sapi atau daging rusa dari pada makan ikan, mereka cepat merasa bosan jika mengkonsumsi ikan. Salah satu cara untuk mengenalkan jenis-jenis ikan dan manfaat makan ikan yakni melalui Pengenalan education fisheries pada siswa sekolah dasar melalui model pembelajaran project based learning.

Pembelajaran project based learning ialah proses pembelajaran yang secara langsung melibatkan siswa untuk menghasilkan sesuatu. Abidin (2007) menjelaskan model pembelajaran ini memiliki karakteristik diantaranya; melibatkan siswa secara langsung dalam pembelajaran, menghubungkan pembelajaran dengan dunia nyata dan Diakhiri dengan menghasilkan sebuah produk olahan ikan. Sedangakan salah satu cara untuk mengatasi kebosanan anak dalam mengkonsumsi ikan yakni dengan kegiatan cooking class. Kegiatan cooking class merupakan kegiatan dimana kita memberikan pelatihan kepada anak-anak tentang produk-produk olahan yang berasal dari ikan. Masyarakat Merauke terutama anak-anak usia sekolah Lebih memilih produk makanan yang berasal dari daging ayam, daging sapi ataupun daging rusa dari pada ikan, maka 
sangat perlu dilakukan pemberdayaan kepada anak-anak agar gemar dalam mengkonsumsi ikan dibandingkan daging. Dengan adanya kegiatan Pengenalan Educations Fisheries diharapkan juga mampu memberikan pengetahuan tentang jenisjenis ikan serta manfaat makan ikan serta memberikan keterampilan kepada anak-anak cara mengolah ikan.

\section{METODE PELAKSANAAN KEGIATAN}

A. Waktu pelaksanaan

Pelaksanan kegiatan pengabdian tentang pengenalan educations fisheries pada siswa sekolah dasar melalui model pembelajaran project based learning dilakukan pada bulan November - Desember 2018.

B. Lokasi dan partisipan kegiatan

kegiatan pengabdian dilakukan di SD Inpres Tanah Miring 1, Kabupaten Merauke. Partisipan kegiatan terdiri dari siwa-siswi kelas IV yang terdiri dari 30 orang.

C. Prosedur Kegiatan

Pelaksanaan kegiatan pengenalan tentang ikan pada siswa sekolah dasar dengan tahapan penguatan kesadaran lewat kegiatan sosialisasi tentang pengetahuan dasar tentang ikan meliputi; 1 . Jenis- jenis ikan di daerah estuari dan jenis-jenis ikan di air tawar, cara membedakan ikan segar dan tidak segar, 2. Pengenalan tentang manfaat makan ikan, 3. Cooking class. Metode yang digunakan adalah sosialisasi berupa pembagian booklet yang didesain semenarik mungkin untuk menarik perhatian siswa-siswi sekolah dasar. Kegiatan selanjutnya mengajarkan bagaimana mengolah ikan agar tidak membosankan saat dikonsumsi yakni dengan menjadikan ikan sebagai produk olahan yang menarik seperti dijadikan perkedel, naget dan bakso.

1. Pengenalan Jenis Ikan (Education Fisheries)

Kegiatan ini dilakukan untuk mengenalkan jenis-jenis ikan melalui pembagian booklet kepada para siswa. Booklet berisikan tentang jenis-jenis ikan yang hidup di air tawar, air laut dan air payau serta bentuk morfologi dari setiap jenis ikan.

2. Pengenalan manfaat makan ikan

Kegiatan pada tahap ini yakni menjelaskan kepada siswa-siswi kelas IV SD Inpres Tanah Miring 1 Kabupaten Merauke tentang manfaat mengkonsumsi Ikan.

3. Cooking class

Kegiatan cooking class merupakan kegiatan mengajarkan kepada anakanak dalam mengolah ikan menjadi beberapa produk makanan yang berbahan dasar ikan. 


\section{HASIL DAN PEMBAHASAN}

Kegiatan pengabdian tentang pengenalan education fisheries pada siswa sekolah dasar melalui model pembelajaran project based learning. Dilakukan dalam dua tahap kegiatan yaitu yang pertama adalah kegiatan sosialisasi kepada siswa tentang education fisheries yakni mengenalkan jenis-jenis ikan yang ada di Merauke pada kegiatan ini kami memberikan booklet kepada siswa yang berisi tentang jenis-jenis ikan yang hidup di air tawar, air payau atau estuari dan air laut, didalam booklet juga dijelaskan tentang morfologi atau ciri-ciri dari ikan yang hidup pada tiga perairan tersebut. Bagian yang terakhir dari booklet ini adalah tentang manfaat ikan bagi manusia.

Pada saat penyampaian materi tentang ikan tim pengabdian membagikan buku tentang pengenalan education fisheries (pendidikan ikan) kepada siswa, selanjutnya dilakukan diskusi antara tim pengabdian dengan para siswa. Sebagian besar siswa hanya mengenal dua tempat hidup bagi ikan yaitu ikan yang hidup di air tawar dan yang hidup di air laut. Sedangkan untuk jenis-jenis ikan para siswa juga hanya mengenal ikan yang ada di air tawar seperti ikan gabus/gastor, ikan mujair, ikan betik, dan ikan lele. Jenis ikan yang hidup di laut seperti ikan kakap, ikan duri, dan ikan kuro.

Tempat hidup bagi ikan berdasarkan buku yang diberikan kepada siswa berisi tentang tiga tempat hidup bagi ikan yaitu ikan yang hidup di air tawar, air payau/estuari dan ikan laut. Jenis-jenis ikan yang hidup di air tawar, air payau dan air laut. Morfologi ikan dan manfaat mengkonsumsi ikan bagi tubuh manusia. Pada saat siswa disuruh menyebutkan ikan yang hidup air payau hampir sebagian siswa belum mengenal jenisjenis ikan yang terdapat dalam buku. Namun ada beberapa yang pernah melihat jenisjenis ikan tersebut.

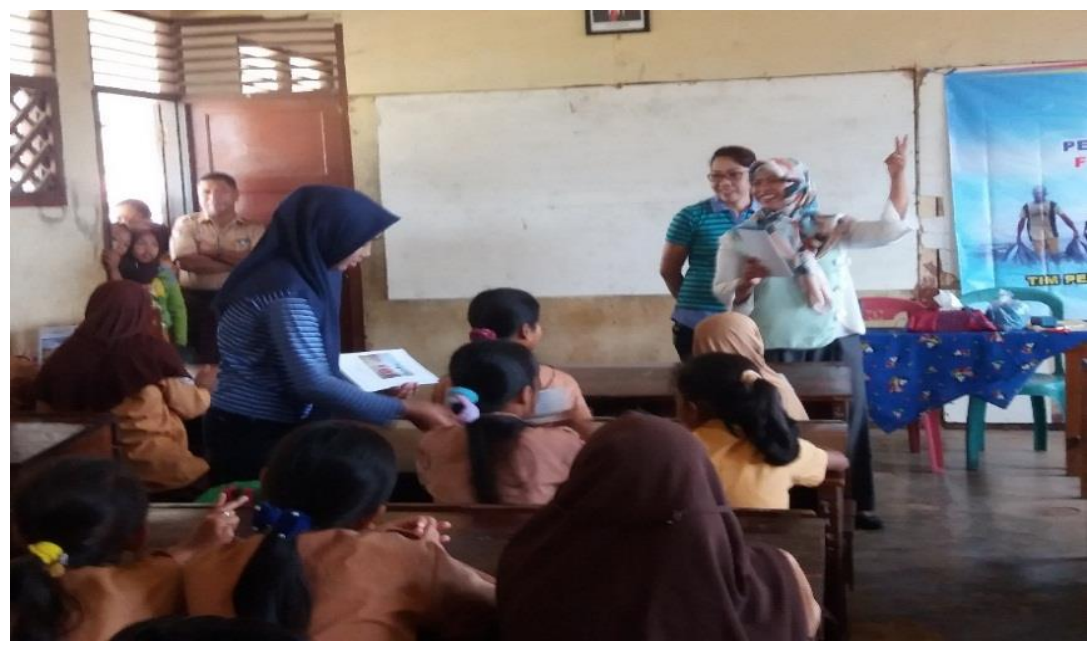

Gambar 1. Kegiatan Pembagian Booklet tentang Jenis-jenis lkan

Siswa kelas V SD Inpres Tanah Miring 1 Kabupaten Merauke sangat memahami tentang jenis-jenis ikan yang yang hidup di air tawar dikarenakan tempat tinggal mereka berada di daerah pertanian yang banyak terdapat saluran-saluran air dimana pada saluran air tersebut pada saat musim kemarau banyak terdapat jenis-jenis ikan seperti ikan mujair, ikan betik maupun ikan lele. Dengan demikian pada saat ditanya tentang jenis-jenis ikan yang hidup di air tawar semua siswa mampu menyebutkannya, beserta 
ciri-ciri dari setiap jenis ikan yang hidup di air tawar. Sedangkan untuk jenis-jenis ikan air laut dan air payau para siswa masih banyak yang belum mengenal. Setelah membaca buku yang diberikan para siswa diharapkan mampu memahami tentang jenisjenis ikan yang ada di perairan payau maupun yang ada di perairan laut terutama jenisjenis ikan yang ada di kota Merauke. Kegiatan selanjutnya yaitu mengenalkan kepada para siswa tentang pentingnya kita mengkonsumsi ikan. Pada saat ditanya hampir semua para siswa mengatakan suka makan ikan.

Kegiatan Cooking class (Kelas Memasak/Program Memasak) adalah kegiatan memasak aneka macam olahan dari ikan diantaranya naget ikan, cilok ikan dan perkedel ikan makanan dengan melibatkan anak-anak secara langsung selama proses memasak. Kegiatan memasak dimulai dari mempersiapkan bahan dan peralatan masak yang digunakan, proses pengolahan bahan, hingga siap untuk dimakan."

Sebelum kegiatan dimulai tim pengabdian membagikan brosur kepada para siswa untuk dipelajari dan diterapkan di rumah masing-masing, dalam melakukan demo masak kita memanfaatkan bahan-bahan yang banyak dijumpai didaerah desa tersebut. Mengenalkan alat dan bahan. Produk olahan ikan yang di masak adalah Naget ikan, cilok ikan dan perkedel ikan. Menu masakan semua berbahan dasar Ikan yang banyak dijumpai. Pada saat kegiatan tim pengabdian mengajarkan cara memfillet ikan agar duri ikan tidak ikut terolah, lalu di giling.

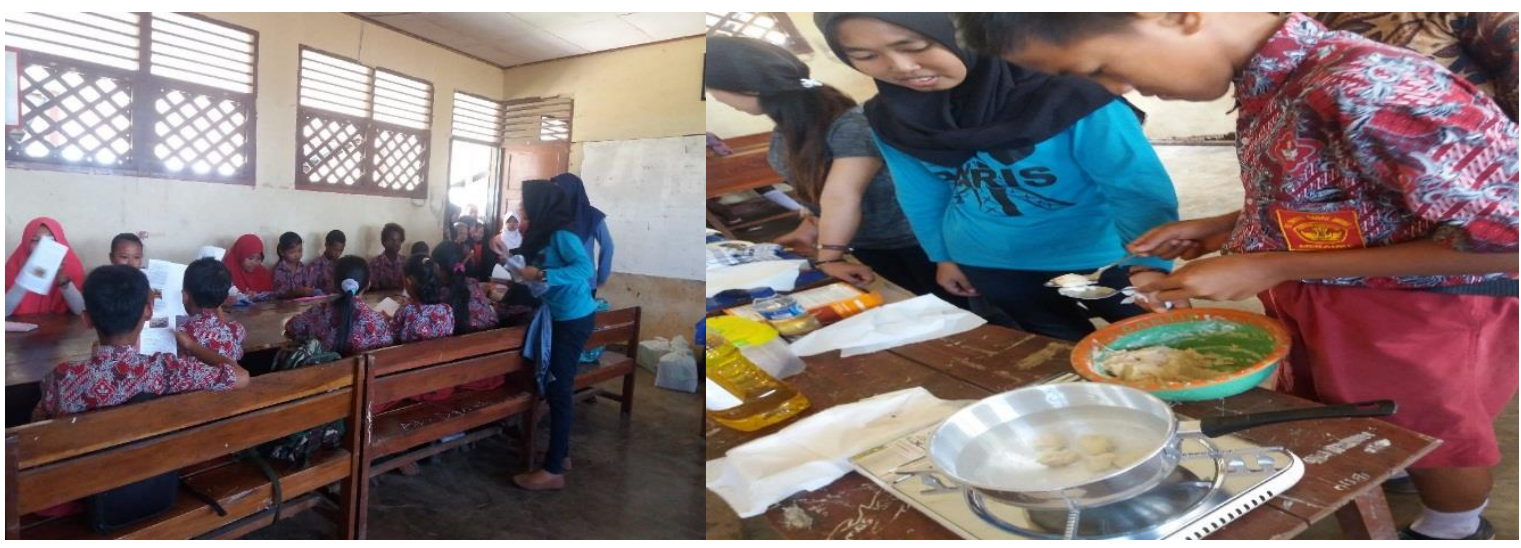

Gambar 2. Kegiatan Cooking Class

\section{KESIMPULAN}

1. Dengan adanya kegiatan pengabdian ini para siswa dapat membedakan jenis-jenis ikan yang hidup di daerah estuari dengan jenis-jenis ikan yang hidup di air tawar maupun yang hidup di air laut.

2. Siswa mengetahui manfaat makan ikan.

3. Siswa dapat mengetahui beberapa produk olahan dari ikan menjadi makanan yang menarik dan lebih digemari olah anak-anak. 


\section{DAFTAR PUSTAKA}

Marsetyo dan Kartasapoetra, 2003. Ilmu gizi, korelasi gizi, kesehatan dan produktivitas kerja, penerbit rineka cipta .jakarta.

Nur Sokib, nurheni S.Palupi dan Budi Suharjo. 2012. Strategi peningkatan konsumsi ikan di kota depok, jawa barat. Manajemen IKM, September 2012.

Pemerintah Daerah Kabupaten Merauke.2015.www.merauke.go.id 